\title{
Further Studies on Genetic Transformation in Rhizobium
}

\author{
By J. L. RAINA AND V. V. MODI \\ Department of Microbiology, M.S. University of Baroda, Baroda, India
}

(Accepted for publication 5 December 1970)

\begin{abstract}
SUMMARY
A strain of Rhizobium cowpea transformed interspecifically and intraspecifically for the gelatinase marker showed maximum competence in the early log phase of growth which was increased further by the addition of Casamino acids and $\mathrm{Mg}^{2+}$ to the competence medium at $\mathrm{pH} 7 \cdot 0$. Ferric ions inhibited transformation and this effect was partially reversed by addition of EDTA. The DNA concentration for maximum frequency of transformation was about $20 \mu \mathrm{g}$. $/ \mathrm{ml}$. The frequency of intraspecific transformation was ten times higher than that of interspecific transformation although the $\mathrm{G}+\mathrm{C}$ mole per cent of the donor and recipient was very similar, 64.0 and 64.5 respectively. A surface-bound nuclease specific for the transforming DNA could have resulted in the high donor DNA requirement.
\end{abstract}

\section{INTRODUCTION}

Genetic transformation induced by heterologous DNA was reported for the first time in Rhizobium by Balassa (1954). Interspecific and intraspecific transformation has since been shown to be a common phenomenon, taking place between many species of Pneumococcus (Bracco, Krauss, Roe \& Macleod, 1957), Streptococcus (Pakula, Hulanicka \& Walczak, I958), Neisseria (Catlin, I960) and Bacillus (Marmur, Seaman \& Levine, 1963). The frequency of interspecific transformation is usually much lower than that of the corresponding intraspecific transformation. Although the ratio of the heterospecific transformation to that of homospecific transformation reveals kinship based on a certain degree of homology between the two types, it has been observed that the lethality of the heterospecific DNA on the recipient cell is an important factor in the low efficiency of heterospecific transformation in Haemophilus (Steinhart \& Herriott, 1968).

Previous studies in our laboratory have been concerned with the transformation of species of Rhizobium using penicillinase and fructokinase production as the markers in one system (Gadre, Mazumdar, Modi \& Parekh, 1967), and adenine independence in the other (Raina \& Modi, I969). While studying these biochemical characteristics, a few strains belonging to the Rhizobium cowpea group were found to be unable to degrade gelatin. As no other biochemical differences which could be used as genetic markers were detected, gelatin liquification was used in investigations to establish conditions for interspecific and intraspecific transformation in Rhizobium.

\section{METHODS}

Strains and media. The various strains and species used in the present study were kindly supplied by Dr G. Rangaswamy, Agricultural University, Bangalore, India. 
The cultures were maintained on mannitol yeast extract agar slants (mannitol $\mathrm{x} \cdot 0 \%$, $\mathrm{w} / \mathrm{v}$, Difco yeast extract $0.1 \%, \mathrm{w} / \mathrm{v}$, agar $2 \%, \mathrm{w} / \mathrm{v}$ ) and subcultured every week. The complex media for the development of competence have been described previously (Raina \& Modi, 1969). The minimal medium contained the following (w/v): $\mathrm{K}_{2} \mathrm{HPO}_{4}$, $0.7 \% ; \mathrm{KH}_{2} \mathrm{PO}_{4}, 0.2 \% ; \mathrm{NaCl}, 0.05 \% ; \mathrm{MgSO}_{4} .7 \mathrm{H}_{2} \mathrm{O}, 0.005 \%$; sodium citrate, $0.05 \%$; ammonium sulphate, $0.1 \%$; glucose, $0.2 \%$. The recipient culture after transformation was plated on mannitol yeast extract gelatin agar medium, incubated at $30^{\circ}$ for $24 \mathrm{~h}$. and the transformants scored by overlaying the plates with $15 \% \mathrm{HgCl}_{2}$ in $0.6 \mathrm{~N}-\mathrm{HCl}$. The transformants formed a clear zone against an opaque background.

Characterization of cultures. Of a number of cultures tested, a green gram strain (C I5) belonging to the Rhizobium cowpea group and unable to degrade gelatin (gelatinase $^{-}$) was selected as the recipient. Two strains, one belonging to the groundnut species of the $R$. cowpea group (GR3) and another a french-bean species of the $R$. phaseolus group (Fb 6 ) were able to degrade gelatin (gelatinase ${ }^{+}$) and were used as the donors. DNA was prepared from the two donors by the method described by Raina \& Modi (1969).

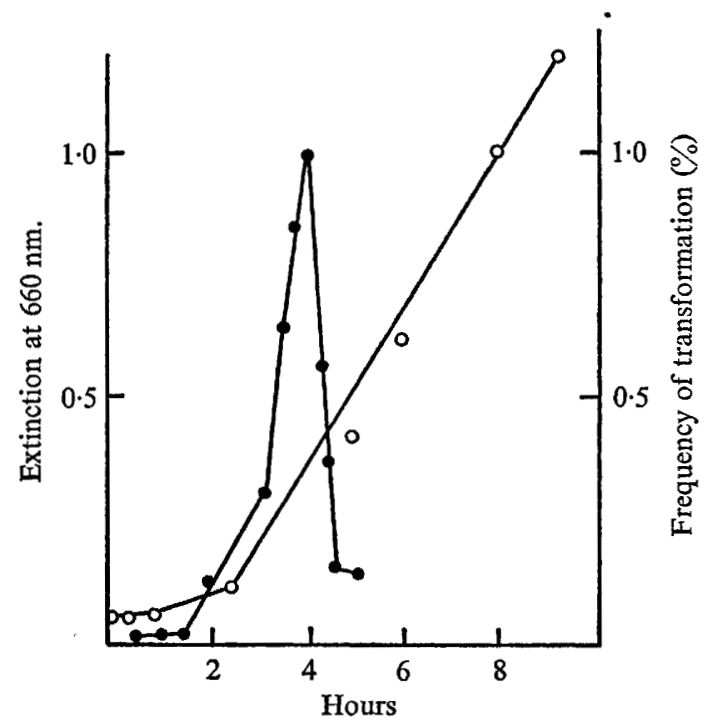

Fig. I. Competence medium was inoculated with an overnight culture of Rhizobium cowpea strain $\mathrm{C} I 5$ to give $\mathrm{I} \times 10^{7}$ organisms $/ \mathrm{ml}$. Growth $(\mathrm{O}-\mathrm{O})$ was measured turbidimetrically at $660 \mathrm{~nm}$. and competence $(-1)$ determined by mixing the recipient with gelatinase ${ }^{+}$ donor DNA $(20 \mu \mathrm{g}$. $/ \mathrm{ml}$.) from $R$. cowpea strain $\mathrm{GR} 3$ and scoring the transformants as described in Methods. Competence is expressed as \% frequency of transformation.

\section{RESULTS}

Competence in relation to the growth phase of the recipient culture and the media used. Cultures of the strain CI5 were made competent by the method of Raina \& Modi (1969). Fig. I shows the growth and the competence of the culture using the gelatinase ${ }^{+}$ GR 3 strain as the donor. Competence is attained essentially in the early log phase, and the culture has to be in an active physiological state. The addition of both Casamino acids and yeast extract to minimal medium resulted in an increased frequency of transformation (Table I). Casamino acids $(2 \mathrm{mg} . / \mathrm{ml}$ ) gave the maximum effect. The 
development of competence is similarly influenced by Casamino acids in Bacillus subtilis, and Wilson \& Bott (I968) attribute this to the presence of inhibitory and stimulatory amino acids which possess chelating properties. Since the development of competence was slightly enhanced by $\mathrm{Mg}^{2+}$ and $\mathrm{Ca}^{2+}$ ions and inhibited by $\mathrm{Fe}^{3+}$, $\mathrm{Mo}^{2+}$ and $\mathrm{Zn}^{2+}$ (Table 2) and since the inhibition due to ferric ions was partially reversed by EDTA, the chelating effect of Casamino acids could be the possible reason for its stimulatory effect. $\mathrm{MgSO}_{4}$ at a concentration of $0.05 \mu \mathrm{g}$. $/ \mathrm{ml}$. was found to give the maximum stimulatory effect.

Table I. Effect of medium on competence

\begin{tabular}{lc}
\multicolumn{1}{c}{ Medium } & $\begin{array}{c}\text { Frequency of } \\
\text { transformation* }(\%)\end{array}$ \\
Complex (control) & 0.07 \\
Minimal & 0.005 \\
Minimal + yeast extract I mg./ml. & 0.03 \\
Minimal + yeast extract $2 \mathrm{mg} . / \mathrm{ml}$. & 0.03 \\
Minimal + Casamino acids I mg./ml. & 0.13 \\
Minimal + yeast extract and & 0.12 \\
Casamino acids I mg./ml. & 0.25 \\
Minimal + Casamino acids $2 \mathrm{mg} . / \mathrm{ml}$. & 0.25 \\
Minimal + Casamino acids 2.5 mg./ml. & \\
\multicolumn{2}{c}{ * Donor: Rhizobium phaseolus strain $\mathrm{Fb} \mathrm{I6.}$}
\end{tabular}

Table 2. Effect of divalent cations on competence

$\begin{array}{cc}\text { Ions added (0.0I } \mu \mathrm{g} . / \mathrm{ml} .) & \begin{array}{c}\text { Frequency of } \\ \text { transformation* }\end{array} \\ \mathrm{None} & 0.072 \\ \mathrm{Mg}^{2+} & 0.090 \\ \mathrm{Ca}^{2+} & 0.083 \\ \mathrm{Zn}^{2+} & 0.030 \\ \mathrm{Mo}^{2+} & 0.016 \\ \mathrm{Fe}^{3+} & 0.002 \\ \mathrm{Fe}+\text { EDTA } 5 \mu \text { moles/ml. } & 0.033 \\ \text { * Donor: Rhizobium phaseolus strain } \mathrm{Fb} \mathrm{I} 6 .\end{array}$

The effect of $\mathrm{pH}$ on competence. $\mathrm{pH}$ was found to influence competence (Table 3). Maximum frequency of transformation was obtained at $\mathrm{pH} 77^{\circ}$. All cultures at the beginning of incubation in competence medium contained $5 \times 10^{6}$ organisms $/ \mathrm{ml}$. The viable count at the end of this incubation was $5 \times 10^{8} / \mathrm{ml}$. at $\mathrm{pH} 7^{\circ}$, but at $\mathrm{pH} 4^{\circ} 0,5^{\circ}$, $6 \cdot 0$ it was only I to $4 \times \mathrm{IO}^{7}$ organisms $/ \mathrm{ml}$. At $\mathrm{pH}$ values greater than 7.0 viability was invariably unaffected but the frequency of transformation was reduced.

The effect of DNA concentration on transformation. Competent cultures were treated with DNA at various concentrations, incubated for $30 \mathrm{~min}$. at $30^{\circ}$ and the reaction terminated by the addition of DNAase at $50 \mu \mathrm{g}$. $/ \mathrm{ml}$. and $\mathrm{MgCl}_{2}$ at $5 \mathrm{~mm}$. Further incubation was carried out for 30 min., and after appropriate dilution samples were plated on gelatin containing agar medium. Table 4 shows the relative frequencies of transformation obtained with different concentrations of DNA; the optimum concentration appears to be $20 \mu \mathrm{g}$. $/ \mathrm{ml}$. Exposure to DNA for a further $15 \mathrm{~min}$. gave no further increase in frequency of transformation. 
Transformation with DNA from different donors. The $\mathrm{C} 15$ recipient strain was transformed by the DNA from the two donors Fb I6 and GR 3 under optimum conditions with respect to growth phase of the recipient, $\mathrm{pH}$, medium supplementation and DNA concentration. The frequency of transformation was ten times greater with a donor from the same group as the recipient than with a donor from a different group, thus showing that genetically homologous DNA has a better chance of bringing about transformation than heterologous DNA. A similar conclusion was reached by Steinhart \& Herriott (1968) and Chen \& Ravin (1966).

Table 3. The effect of $p H$ on competence

$\begin{array}{cc}\begin{array}{c}\mathrm{pH} \text { of the competence } \\ \text { medium }\end{array} & \begin{array}{c}\text { Frequency of } \\ \text { transformation* }(\%)\end{array} \\ 4.0 & \text { Nil } \\ 5.0 & \text { Nil } \\ 6.0 & 0.05 \\ 7.0 \text { (Control) } & 0.08 \\ 8.0 & 0.055 \\ 9.0 & 0.018 \\ \text { * Donor: Rhizobium phaseolus strain } \mathrm{Fb} 16 .\end{array}$

Table" 4 . The effect of the concentration of DNA on the frequency of transformation

$\begin{array}{cc}\text { DNA }(\mu \mathrm{g} . / \mathrm{ml} .) & \begin{array}{c}\text { Frequency of } \\ \text { transformation* }(\%)\end{array} \\ 10 \cdot 0 & 0.40 \\ 12.5 & 0.50 \\ 15.0 & 0.55 \\ 17.5 & 0.70 \\ 20.0 & 0.75 \\ 22.0 & 0.70 \\ * & \\ * & \text { Donor: Rhizobium cowpea strain GR 3. }\end{array}$

Using the method of Wang (1968) the $\mathrm{G}+\mathrm{C}$ content of the DNA from bacteria of Rhizobium phaseolus group had a $\mathrm{G}+\mathrm{C}$ content of 64 mole $\%$ whereas that from $R$. cowpea was 64.5 mole $\%$. This suggests genetic homology between these species on the basis of GC content. Thus reduced frequency of interspecific transformation must implicate factors other than just DNA homology.

It is likely that the requirement for a high concentration of transforming DNA in the Rhizobium system, similar to that for reciprocal transformation between Agrobacterium and Rhizobium (Kern, 1969), is relevant here. Experiments with the C I 5 transformable recipient indicate the presence of two nucleases, one specific for transforming DNA on the cell surface which has a pH optimum of $8 \cdot 5$, and the other inside the cell, specific for denatured DNA and with a pH optimum of $9^{\circ} 0$. The two enzymes also differed in their $\mathrm{Mg}^{2+}$ ion requirements, and effective enzyme concentrations and times of incubation, at the same substrate concentration. The two proteins have been purified three- and I2-fold respectively by ammonium sulphate fractionation, and the former purified a further tenfold by Sephadex column chromatography. The significance of such enzymes as these has been discussed by Kohoutova \& Malek (I966). Membrane-bound nuclease specific for denatured DNA was reported by Birnboim (1966) in a trans- 
formable species of Bacillus subtilis, and the author suggested that it may influence the process of transformation. The requirement for a high concentration of transforming DNA in the Rhizobium system may therefore be attributed to the presence of surfacebound nuclease.

This work was supported by grant no. PL-480/FG-IN-394 from the Agricultural Research Service of the U.S. Department of Agriculture.

\section{REFERENCES}

Balassa, R. (1954). Transformation mechanismen der Rhizobium I-III. Acta microbiologica Academiae scientiarum Hungaricae 2, $5 \mathrm{I}-78$.

BirnBorm, H. C. (1966). Cellular sites in B. subtilis of nuclease which preferentially degrades single stranded nucleic acids. Journal of Bacteriology 9I, 1004-101 I.

Bracco, R., Krauss, M. R., RoE, A. S. \& MACLEOD, C. M. (1957). Transformation reaction between Pneumococcus and three strains of Streptococcus. Journal of Experimental Medicine 106, 247-259.

CATLIN, W. (1960). Interspecific transformation of Neisseria by cultural strains containing deoxyribonucleate. Science, New York 131, 608-6ro.

Chen, K. C. \& Ravin, A. W. (1966). Heterospecific transformation of Pneumococcus and Streptococcus. I. Relative efficiency and specificity of DNA helping effect. Journal of Molecular Biology 22, 109-12I.

Gadre, S. V., Mazumdar, L., Modi, V. V. \& Parekh, V. (1967). Interspecific transformation in Rhizobium. Archiv für Mikrobiologie 57, 388-391.

Kern, H. (1969). Interspecific transformation between Agrobacterium tumifaciens and Rhizobium leguminosarum. Archiv für Mikrobiologie 66, 63-68.

Kohoutova, M. \& MALEK, I. (1966). The Physiology of Gene and Mutation Expression. Edited by M. Kohoutova \& J. Hubacek. Prague: Academia.

Marmur, J., Seaman, E. \& Levine, J. (1963). Interspecific transformation in B. subtilis. Journal of Bacteriology 85, 46I-467.

PaKUla, R., Hulanicka, E. \& WalczaK, W. (1958). Transformation reactions between streptococci, pneumococci and staphylococci. Bulletin de l'Académie polonaise des sciences. Série des sciences biologiques 6, 325-328.

RaINA, J. L. \& ModI, V. V. (1969). Genetic transformation in Rhizobium. Journal of General Microbiology 57, 125-130.

STEINHART, W. L. \& HERRIOTT, R. M. (1968). Genetic integration in the heterospecific transformation of Haemophilus influenzae cells by Haemophilus parainfluenzae deoxyribonucleic acid. Journal of Bacteriology 96, 1725-1731.

WANG, S. Y. (1968). The determination of nucleic acid base composition by chemical reactivity. In Methods in Enzymology, vol. 12, part B. Edited by L. Grossman and K. Moldave. New York: Academic Press.

Wruson, G. A. \& BotT, K. F. (1968). Nutritional factors influencing the development of competence in Bacillus subtilis. Journal of Bacteriology 95, 1439-1449. 